\title{
PENERAPAN MODEL PEMBELAJARAN INKUIRI UNTUK MENINGKATKAN MOTIVASI DAN HASIL BELAJAR PESERTA DIDIK PADA MATERI GELOMBANG
}

\author{
Andrianis* \\ Guru SMA Negeri 1 Bandar Baru \\ *Korespondensi: adrianis887@gmail.com
}

\begin{abstract}
Abstrak: Penelitian ini bertujuan untuk mengetahui penerapan model pembelajaran inkuiri sebagai upaya meningkatkan motivasi dan hasil belajar fisika pada materi gelombang peserta didik kelas XI IPA-2 SMA Negeri 1 Bandar Baru Tahun Ajaran 2019/2020. Penelitian ini termasuk kepada Penelitian Tindakan Kelas (PTK). Pelaksanaannya di SMA Negeri 1 Bandar Baru Tahun Ajaran 2019/2020 dalam kurun waktu 3 bulan. Subjek penelitiannya yaitu peserta didik Kelas XI IPA-2 berjumlah 30 orang data PTK ini dari peserta didik, hasil belajar peserta didik ,observasi dan dokumentasi. Untuk memperoleh data ini menggunakan instrumen tes dan lembar observasi. Analisis data dilakukan secara deskriptif kualitatitif dengan mencari jumlah ketuntasan dan ketidak tuntasan peserta didik setiap tatap muka. Analisis dilakukan dengan cara mencari nilai tertinggi, terendah dan rata-rata. Hasil temuan penelitian menununjukan peningkatan hasil belajar peserta didik dari $75.66 \%$ pada Siklus 1 meningkat menjadi $22 \%$ pada pertemuan 2, dan pada siklus 2 juga terjadi peningkatan yakni $64 \%$ pada pertemuan 1 meningkat menjadi 86,66 \% pada siklus kedua dikatagorikan baik melalui Penerapan Model Pembelajaran Inkuiri Untuk Meningkatkan Hasil Belajar Fisika Pada Materi Gelombang Peserta didik Kelas XI IPA -2 SMA Negeri 1 Bandar Baru Tahun Ajaran 2019/2020.
\end{abstract}

Kata Kunci: Motivasi, Hasil Belajar, Inkuiri, Gelombang.

\section{APPLICATION OF INQUIRY LEARNING MODELS TO INCREASE STUDENT MOTIVATION AND LEARNING OUTCOMES ON WAVE MATERIALS}

\begin{abstract}
Abtrack: This study aims to apply the inquiry learning model as an effort to increase motivation and physics learning outcomes in the wave material of class XI IPA-2 students of SMA Negeri 1 Bandar Baru for the 2019/2020 academic year. This research is included in Classroom Action Research (PTK). This will be held at SMA Negeri 1 Bandar Baru for the 2019/2020 academic year within 3 months. The research subjects were students of class XI IPA-2 assessing 30 people of this CAR data from students, student learning outcomes, observation and documentation. To obtain this data using test instruments and observation sheets. The data analysis was conducted in a descriptive qualitative manner by asking for the number of completeness and incompleteness of the students each face to face. The analysis is done by looking for the highest, lowest and average values. The results of the research findings showed an increase in student learning outcomes from $75.66 \%$ in cycle 1 increased to $22 \%$ at meeting 2, and in cycle 2 there was also an increase in that 64\% at meeting 1 increased to $86.66 \%$ in the second cycle was categorized as good through the application of learning models Inquiry to Improve Physics Learning Outcomes in the Wave Material of Class XI IPA-2 Students of SMA Negeri 1 Bandar Baru for the 2019/2020 academic year.
\end{abstract}

Keywords: Motivation, Learning Outcomes, Inquiry, Wave. 


\section{PENDAHULUAN}

Kualitas kehidupan bangsa sangat ditentukan oleh faktor pendidikan. Peran pendidikan sangat penting untuk menciptakan kehidupan yang cerdas, damai, terbuka, dan demokratis. Oleh karena itu, pembaharuan pendidikan harus selalu dilakukan untuk meningkatkan kualitas pendidikan nasional. Menurut (Muhardi, 2005) kemajuan suatu bangsa hanya dapat dicapai melalui penataan pendidikan yang baik. Upaya peningkatan mutu pendidikan itu diharapkan dapat menaikkan harkat dan martabat manusia Indonesia. Untuk mencapai itu pendidikan harus adaptif terhadap perubahan zaman.

Pendidikan merupakan faktor yang sangat penting dalam kehidupan manusia, karena dengan pendidikan diharapkan manusia dapat mengembangkan pengetahuan,ketrampilandan kreativitas.Tugas pendidik tidak hanya menyampaikan sejumlah informasi kepada peserta didik,tetapi mengusahakan bagaimana agar konsep-konsep penting berguna bagi peserta didik. Menurut (Raharjo, 2013) Pendidikan dapat juga diartikan sebagai proses dengan metodemetode tertentu sehingga peserta didik memperoleh pengetahuan, pemahaman,dan cara bertingkah laku yang sesuai dengan kebutuhan. Bertitik tolak dari penjelasan tersebut, maka seorang guru diharapkan memiliki kemampuan dalam memilih strategi apa yang tepat digunakan untuk melaksanakan proses pembelajaran di kelasnya, sehingga tujuan yang telah dituliskan dalam rencana pembelajaran dapat tercapai. Jadi jelaslah bahwa seorang guru dituntut untuk menguasai metode.

Proses pembelajaran selama ini seringkali berorientasi pada terselesaikannya materi pembelajaran saja bukan pada ketercapaian tujuan pembelajaran yakni peningkatan kompetensi peserta didik. Kompetensi diantaranya hasil belajar maupun kemandirian peserta didik dalam pembelajaran. Dapat diartikan bahwa model-model pembelajaran yang diterapkan selama ini cenderung terlalu teoritik dan melupakan peningkatan kompetensi pada diri peserta didik.

Menurut (Wahyudi, 2010) Langkah-langkah seorang guru sebelum menentukan metode pembelajaran adalah memperhatikan persiapan pembelajaran yang meliputi pemahaman terhadap tujuan pembelajaran, penguasaan materi pelajaran,dan pemahaman teoriteori pendidikan selainteori-teori pengajaran.Seorang guru juga harus memahami prinsipprinsip pembelajaran dan model-model serta prinsip evaluasinya, sehingga pada akhirnya pembelajaran berlangsung secara cepat dan tepat. Selain itu, menurut (Nurdyansyah \& Fahyuni, 2016) kegiatan pembelajaran seharusnya dirancang untuk memberikan pengalaman belajar yang melibatkan proses mental dan fisik melalui interaksi antar sesama peserta didik, peserta didik dengan guru, lingkungan dan sumber belajar dalam rangka pencapaian kompetensi dasar. Pengalaman belajar dapat terwujud melalui penggunaan pendekatan pembelajaran yang bervariasi dan berpusat pada peserta didik.

Hasil observasi awal penelitian didapatkan pembelajaran fisika SMA Negeri 1 Bandar Baru Tahun Ajaran 2019/2020 pada kelas XI IPA-2 Pembelajaran sangat monoton. Terutama pada materi gelombang. Pembelajaran ini guru sebagai pusat pembelajaran. Metode pembelajaran yang digunakan adalah ceramah, tanya jawab, dan mengerjakan soal yang ada pada buku LKS ( Lembar Kerja Peserta didik) akibatnya dalam mempelajari fisika peserta 
didik cenderung kurang semangat, malas, jenuh dan dianggap sebagai pelajaran yang membosankan dan monoton. Hal ini berakibat pada prestasi belajar yang rendah.Berdasarkan tes yang telah dilaksanakan, nilai rata-rata anak belum mencapai KKM. Peserta didik yang mencapai nilai KKM kurang dari 25\%, dari niali Nilai KKM pembelajaran yang ditentukan yaitu sebesar 65. Hal ini disebabkan selama ini proses pembelajaran masih bersifat konvensional. Penggunaan metode konvensional hanya sedikit membantu keaktifan peserta didik dalam belajar dan peserta didik hasil belajar yang diperoleh masih rendah.

Berdasarkan hal tersebut, peneliti ingin mencari alternatif yang lebih baik untuk meningkatkan prestasi dan hasil belajar peserta didik. Salah satu alternatif yang dapat dilakukan adalah menerapkan metode inkuiri dalam proses pembelajaran pada materi gelombang. Menurut (Ardiannisa et al., 2020) dalam pemebelajaran inkuiri peserta didik memperoleh petunjuk-petunjuk seperlunya, berupa pertanyaan-pertanyaan yang bersifat membimbing. Pada awalnya dilakukan lebih banyak bimbingan tapi lambat laun dikurangi. (Rofiah et al., 2018) menambahkan tujuan pembelajaran inkuiri adalah agar peserta didik belajar melaksanakan metode ilmiah dan kemudian mampu menerapkan pada pemecahan masalah. Model pembelajaran ini dirasa mampu mengembangkan pengetahuan peserta didik karena disini peserta didik dapat menemukan berbagai pokok permasalahan, kemudian memecahkan. Dengan pemecahan masalah ini peserta didik akan lebih paham terhadap permasalahan yang dihadapi dalam mata pelajaran. Selain itu, menurut (Dwi Apriliani et al., 2019) metode pembelajaran inkuiri perlu diterapkan dalam pembelajaran sains karena dapat berpengaruh terhadap hasil belajar peserta didik. Oleh sebab itu, peneliti berkeinginan menerapkan strategi pembelajaran dengan inkuiri agar dapat meningkatkan kemandirian dan hasil belajar peserta didik.

Peneliti memfokuskan penelitian pada Model pembelajaran dalam pembelajaran fisika harus berubah dan melibatkan peserta didik. Hal ini dilakukan supaya peserta didik tidak lagi merasa bosan dalam mengikuti pelajaran fisika. Peserta didik diharapkan lebih aktif tidak lagi hanya sekedar menerima informasi atau diceramahi guru, tetapi bisa memberikan informasi kepada teman-temannya. Untuk itu peneliti bekerjasama dengan guru mata pelajaran fisika mencoba berusaha meningkatkan motivasi dan hasil belajar anak didik dengan menerapkan model pembelajaran inkuiri.

\section{METODE}

Jenis penelitian ini adalah penelitian tindakan kelas yang terdiri dari perencanaan, pelaksanaan tindakan, observasi dan refleksi dengan menggunakan model pembelajaran Inkuiri. Subyek penelitian tindakan kelas ini adalah peserta didik Kelas XI IPA-2 SMA Negeri 1 Bandar Baru Tahun Ajaran 2019/2020. Jumlah peserta didik adalah 30 orang dengan lakilaki sebanyak 20 orang dan perempuan 10 orang. Teknik pengumpulan data pada penelitian ini, dilakukan dengan cara mengumpulkan hasil nilai tes. Tes dilaksanakan pada setiap akhir pembelajaran pada setiap siklus, dengan menggunakan soal tes secara tertulis dalam bentuk essay.

Analisis data hasil belajar dilakukan dengan rumus persentase menurut Sugiono (2010): 


$$
P=\frac{\text { jumlah siswa yang tuntas }}{\text { jumlah siswa seluruhnya }} \times 100 \%
$$

Keberhasilan penelitian tindakan kelas ini ditentukan oleh Indikator penelitian. Indikator penelitian ini dapat dilihat pada tabel 1.

Tabel 1. Indikator penelitian

\begin{tabular}{|c|c|c|c|}
\hline No. & Ukuran indikator & Capaian siklus 1 & Capaian siklus 2 \\
\hline 1 & $\begin{array}{l}\text { Peserta didik yang } \\
\text { mencapai angka KKM ( } \\
\text { nilai } \geq 70)\end{array}$ & $\geq 75.00 \%$ & $\geq 90.00 \%$ \\
\hline 2 & Nilai rata-rata kelas & $\geq 70.00$ & $\geq 80.00$ \\
\hline 3 & $\begin{array}{l}\text { Peserta didik yang } \\
\text { Berprestasi dalam proses } \\
\text { pembelajaran }\end{array}$ & Cukup & Baik \\
\hline
\end{tabular}

\section{HASIL DAN PEMBAHASAN}

Penerapan model Inkuiri pada pelajaran Fisika di kelas XI IPA-2 telah memberikan manfaat yang sangat baik terhadap peningkatan motivasi dan hasil belajar yang diperoleh oleh peserta didik kelas XI IPA-2 terutama pada materi gelombang.

Selama ini, pelaksanaan pembelajaran Fisika pada materi Gelombang di SMA Negeri 1 Bandar Baru Tahun Ajaran 2019/2020 masih besifat konvensional dan belum menggunakan sebuah model pembelajaran yang dapat membantu meningkatkan motivasi dan hasil belajar peserta didik menjadi lebih baik. Dalam penerapan metode secara konvensional, terlihat peserta didik merasa bosan, dan tidak berkonsentrasi dalam melakukan pembelajaran prestasi belajar peserta didik hanya mendengar materi yang disampaikan oleh guru,sehingga Motivasi belajar peserta didik dalam pembelajaran menjadi kurang aktif. Rendahnya prestasi peserta didik dalam belajarn mempengaruhi hasil belajar peserta didik yang semakin rendah pula.

Penerapan model Inkuiri pada siklus I telah memperlihatkan adanya peningkatan hasil belajar peserta didik menjadi lebih baik jika dibandingkan hasil pra siklus yang diperoleh peserta didik pada saat pra siklus. Pada siklus I, masih terdapat peserta didik yang belum mengalami ketuntasan hasil belajar yang sesuai dengan nilai KKM yang telah ditetapkan. Akan tetapi telah terlihat adanya peningkatan hasil belajar yang lebih baik jika dibandingkan dengan hasil belajar yang di peroleh pada saat pra siklus. Hal ini menandakan bahwa model Inkuiri secara perlahan mampu memberikan dampak yang baik dalam membantu meningkatkan motivasi dan hasil belajar peserta didik menjadi lebih baik (Firman et al., 2019). Persentase ketuntasan yang didapatkan pada siklus I, telah mencapai indikator siklus I yang ingin dicapai oleh peneliti.

Berdasarkan hasil belajar yang diperoleh dari hasil test, hasil dari observasi serta refleksi yang telah dilakukan pada siklus I, maka perbaikan yang telah dilakukan oleh peneliti pada siklus II, telah memberikan hasil yang sesuai dengan harapan penulis. Pada siklus II, 
terlihat adanya peningkatan hasil belajar yang diperoleh oleh peserta didik menjadi lebih baik. Pada siklus II, persentase ketuntasan peserta didik telah mengalami peningkatan dan telah mencapai indikator siklus II yang ditetapkan oleh peneliti.

Pada siklus II, semua peserta didik mengalami peningkatan hasil belajar yang lebih baik jika dibandingkan dengan sklus I. Hal ini mendakan bahwa penerapan model Inkuiri telah mampu memberikan respon yang sangat baik dalam menunjang peningkatan motivasi dan hasil belajar peserta didik menjadi lebih baik lagi. Berdasarkan hasil penelitian yang telah dilakukan pada siklus I dan II, penerapan model Inkuiri telah memberikan nilai yang positif terhadap peningkatan hasil belajar Fisika peserta didik terutama pada materi gelombang. Perbandingan persentase hasil belajar peserta didik pada siklus I dan II dapat dilihat pada Gambar 1.

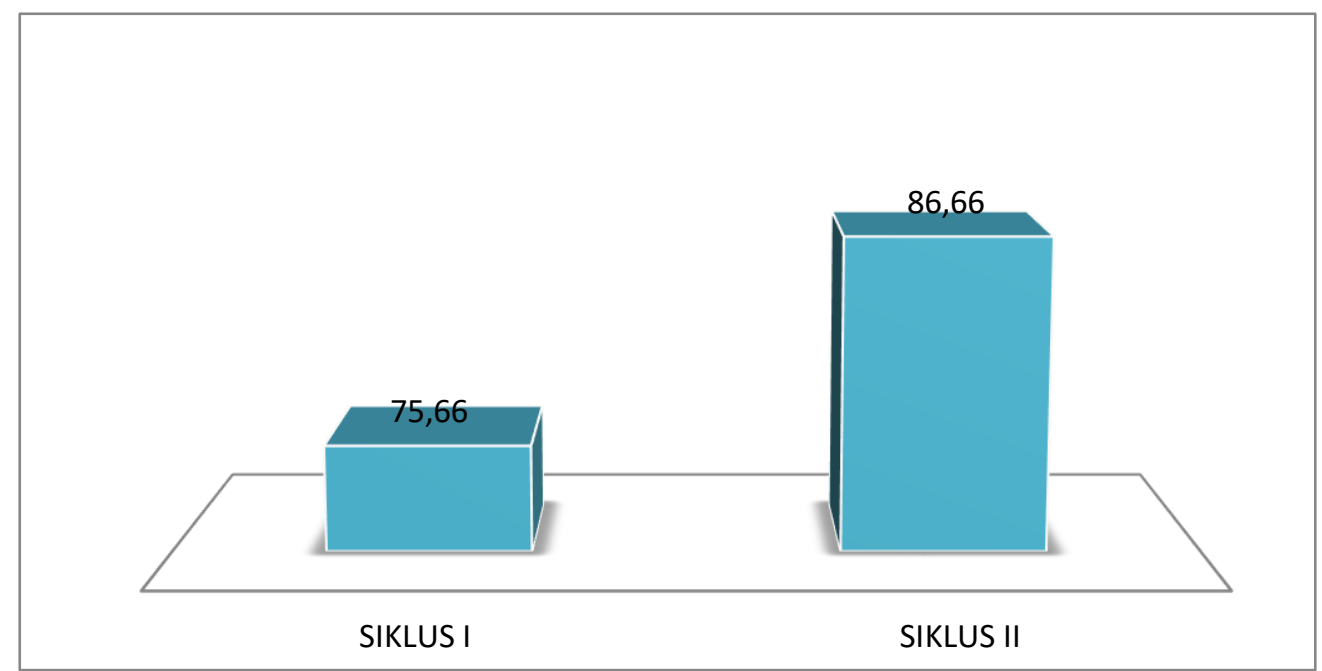

Gambar 1. Grafik Perbandingan persentase hasil belajar peserta didik pada siklus I dan II

Berdasrkan gambar 1, terlihat bahwa adanya peningkatan hasil belajar peserta didik dari siklus I ke siklus II. Pada siklus I,penerapan model Inkuiri telah mampu memberikan persentase hasil belajar peserta didik yaitu sebesar $75.66 \%$ dan telah mengalami peningkatan menjadi $86.66 \%$ pada siklus II. Secara rinci perbandingan peningkatan hasil belajar peserta didik siklus I dan II dapat dilihat pada Tabel 4.6.

Tabel 2. Perbandingan peningkatan hasil belajar peserta didik antar siklus

\begin{tabular}{ccc}
\hline Kategori nilai peserta didik & Siklus I & Siklus II \\
\hline Nilai 50 & - & - \\
Nilai 55 & 3 Peserta didik & - \\
Nilai 60 & 1 Peserta didik & - \\
Nilai 65 & 2 Peserta didik & \\
Nilai 70 & 1 Peserta didik & 3 Peserta didik \\
Nilai 75 & 13 Peserta didik & 5 Peserta didik \\
Nilai 80 & 6 Peserta didik & 12 Peserta didik
\end{tabular}




\begin{tabular}{ccc} 
Nilai 85 & 4 Peserta didik & 6 Peserta didik \\
Nilai 90 & - & 4 Peserta didik \\
Nilai 100 & - & - \\
\hline $\begin{array}{c}\text { Jumlah peserta didik tuntas } \\
\text { Jumlah peserta didik tidak }\end{array}$ & 8 & 26 \\
tuntas & 22 & 4 \\
Nilai Rata-rata & 63.16 & 75.26 \\
Persentase ketuntasan & $75.66 \%$ & $86.66 \%$ \\
\hline
\end{tabular}

Berdasarkan Tabel 2, terlihat peningkatan hasil belajar peserta didik pada setiap siklus. Pada siklus I, nilai terendah adalah 60 dan nilai tertinggi adalah 85. Pada siklus II, nilai terendah adalah 65 dan nilai tertinggi adalah 90. Peningkatan hasil belajar peserta didik pada setiap siklus menandakan bahwa penerapan model Inkuiri memberikan pengaruh yang positif dalam meningkatkan hasil belajar peserta didik. Secara keseluruhan, penerapan model Inkuiri telah memberikan peningkatan hasil belajar pada peserta didik dan telah mencapai indikator ketuntasan hasil belajar siklus I dan siklus II yang ditetapkan oleh peneliti.Penerapan model Inkuiri telah meningkatkan prestasi belajar peserta didik antar siklus. Perbandingan Motivasi belajar peserta didik antar siklus dapat dilihat pada Tabel 3.

Tabel 3. Perbandingan Motivasi belajar peserta didik antar siklus

\begin{tabular}{|c|c|c|c|c|c|c|c|c|c|c|c|c|c|}
\hline \multirow[t]{2}{*}{ No } & \multirow[t]{2}{*}{ Aspek yang diamati } & \multicolumn{3}{|c|}{$\begin{array}{c}\text { Nilai siklus I } \\
\text { pertemuan } \\
1\end{array}$} & \multicolumn{3}{|c|}{$\begin{array}{l}\text { Nilai siklus I } \\
\text { pertemuan } 2\end{array}$} & \multicolumn{3}{|c|}{$\begin{array}{l}\text { Nilai siklus } \\
\text { II } \\
\text { pertemuan } 1\end{array}$} & \multicolumn{3}{|c|}{$\begin{array}{c}\text { Nilai } \\
\text { siklus II } \\
\text { pertemuan } \\
2\end{array}$} \\
\hline & & $\mathbf{A}$ & B & C D & A $\mathbf{B}$ & $\mathbf{C}$ & D & A $\mathbf{B}$ & $\mathbf{C}$ & D & $\mathbf{A}$ & B C & D \\
\hline 1. & $\begin{array}{l}\text { Peserta didik } \\
\text { memperhatikan } \\
\text { penjelasan guru }\end{array}$ & & $\sqrt{ }$ & & $\sqrt{ }$ & & & $\sqrt{ }$ & & & $\sqrt{ }$ & & \\
\hline 2. & $\begin{array}{l}\text { Peserta didik } \\
\text { bekerjasama dalam } \\
\text { menyelesaikan tugas } \\
\text { kelompok }\end{array}$ & & & $\sqrt{ }$ & $\sqrt{ }$ & & & $\sqrt{ }$ & & & $\sqrt{ }$ & & \\
\hline 3. & $\begin{array}{l}\text { Peserta didik saling } \\
\text { berdiskusi dalam } \\
\text { kelompok. }\end{array}$ & & & $\sqrt{ }$ & $\sqrt{ }$ & & & $\sqrt{ }$ & & & $\sqrt{ }$ & & \\
\hline 4. & $\begin{array}{l}\text { Peserta didik memiliki } \\
\text { keaktifan dalam bertanya } \\
\text { dan merespon } \\
\text { pertanyaan dari guru. }\end{array}$ & & & $\sqrt{ }$ & & $\sqrt{ }$ & & $\sqrt{ }$ & & & & $\sqrt{ }$ & \\
\hline 5. & $\begin{array}{l}\text { Peserta didik mampu } \\
\text { mengerjakan soal secara } \\
\text { individu }\end{array}$ & & & $\sqrt{ }$ & & $\sqrt{ }$ & & $\sqrt{ }$ & & & & $\sqrt{ }$ & \\
\hline
\end{tabular}




\begin{tabular}{llllll}
\hline 6. & $\begin{array}{l}\text { Peserta didik mengikuti } \\
\text { pembelajaran dengan } \\
\text { aktif dan tertib }\end{array}$ & $\sqrt{ }$ & $\sqrt{ }$ & $\sqrt{ }$ & $\sqrt{ }$ \\
\hline
\end{tabular}

Keterangan:
A :Sangat baik
C : Cukup
B : Baik
D : Kurang

Berdasarkan pada Tabel 3, terlihat bahwa adanya peningkatan kategori Baik dan prestasi belajar peserta didik dalam proses pembelajaran dari siklus I ke siklus II. Hal ini menandakan bahwa penerapan model Inkuiri telah memberikan pengaruh yang positif terhadap peningkatan hasil Motivasi belajar peserta didik menjadi lebih baik. Secara keseluruhan penerapan model Inkuiri telah dapat Meningkatkan Motivasi Belajar Fisika Pada Materi Gelombang Melalui Penerapan Model Pembe lajaran Inkuiri menjadi lebih baik.

\section{PENUTUP}

Berdasarkan Hasil penelitian maka dapat di simpulkan bahwa Melalui Upaya Meningkatkan Motivasi dan Hasil Belajar Fisika Pada Materi Gelombang Melalui Penerapan Model Pembelajaran Inkuiri Pada Peserta didik Kelas XI IPA-2 SMA Negeri 1 Bandar Baru Tahun Ajaran 2019/2020. Hal tersebut ditunjukkan dengan adanya ketercapaian indikator. Dengan model pembelajaran inkuiri dapat meningkatkan motivasi dan hasil belajar fisika pada materi gelombang peserta didik kelas XI IPA-2 SMA Negeri 1 Bandar Baru Tahun Ajaran 2019/2020 yang ditandai dengan adanya perbedaan ketuntasan pada siklus I dan Siklus II. maka dapat diambil kesimpulan sebagai berikut: (1) Motivasi belajar peserta didik dengan penerapan model pembelajaran inkuiri meningkat dari setiap siklus. Pada siklus I motivasi belajar peserta didik dalam pembelajaran mencapai skor rata-rata 63,16, dan siklus II 75,66, (2) Hasil belajar peserta didik dalam memahami materi gelombang dengan penerapan model pembelajaran inkuiri terjadi peningkatan. Hal ini ditandai dengan terus meningkatnya Kualitas belajar peserta didik pada setiap siklus. Siklus I hasil belajar peserta didik mencapai nilai presentase $75.66 \%$, dan pada siklus ke II nilai hasil belajar peserta didik mencapai presentase $86.66 \%$.

\section{DAFTAR PUSTAKA}

Ardiannisa, S., Fonna, M., \& Fatmi, N. (2020). Penerapan Model Inkuiri Terbimbing Untuk Meningkatkan Pemahaman Konsep Siswa Melalui Simulasi Phet Pada Materi Elastisitas Di Sma 2 Bireuen. Relativitas: Jurnal Riset Inovasi Pembelajaran Fisika, 2(2), 1-7.

Dwi Apriliani, N. M. P., Wibawa, I. M. C., \& Rati, N. W. (2019). Pengaruh Model Pembelajaran Inkuiri Terbimbing Terhadap Hasil Belajar Ipa. Jurnal Penelitian Dan Pengembangan Pendidikan.

Firman, M. A., Ertikanto, C., \& Abdurrahman, A. (2019). Description Of Meta-Analysis Of 
Inquiry-Based Learning Of Science In Improving Students' Inquiry Skills. Journal of Physics: Conference Series.

Muhardi. (2005). Kontribusi Pendidikan Dalam Meningkatkan Kualitas Bangsa Indonesia. Journal Unisba.

Nurdyansyah, \& Fahyuni, E. F. (2016). Inovasi Model Pembelajaran Sesuai Kurikulum 2013. In Nizmania Learning Center.

Raharjo, S. B. (2013). Evaluasi Trend Kualitas Pendidikan Di Indonesia. Jurnal Penelitian Dan Evaluasi Pendidikan.

Rofiah, E., Aminah, N. S., \& Sunarno, W. (2018). Pengembangan Modul Pembelajaran Ipa Berbasis High Order Thinking Skill (Hots) Untuk Meningkatkan Kemampuan Berpikir Kritis Siswa Kelas Viii Smp/Mts. Inkuiri: Jurnal Pendidikan Ipa.

Sugiono. (2010). Metode Penelitian Kuantitatif Kualitatif Dan R\&D. Bandung: Alfabeta

Wahyudi. (2010). Standar Kompetensi Profesional Guru. Jurnal Pendidikan Sosiologi Dan Humaniora. 